\title{
PENGARUH MASA MENSTRUASI TERHADAP KADAR HEMOGLOBIN DAN MORFOLOGI ERITROSIT
}

\author{
Sitti Hadijah ${ }^{1}$, Hasnawati $^{2}$, Masyita Putri Hafid ${ }^{3}$ \\ 1,2,3 Jurusan Analis Kesehatan Poltekkes Kemenkes Makassar
}

Koresponden: Shitaku2975@gmail.com

\begin{abstract}
ABSTRAK
Menstruasi merupakan proses fisiologi pelepasan endometrium yang banyak terdapat pembuluh darah dan terjadi setiap satu bulan sekali. siklus menstruasi normalnya 25 sampai 32 hari. Pengeluaran darah selama menstruasi menunjukkan kehilangan simpanan zat besi secara cepat sesuai dengan banyaknya darah yang keluar sedangkan semakin lama wanita mengalami menstruasi maka semakin banyak pula darah yang keluar dan semakin banyak kehilangan timbunan zat besi. Penelitian ini bertujuan untuk menentukan Kadar Hemoglobin dan morfologi eritrosit pada wanita yang mengalami masa menstruasi. Penelitian ini dilakukan di laboratorium RSUD Pangkep menggunakan 20 sampel wanita yang sedang menstruasi. Jenis penelitian ini adalah eksperimen semu (quasi experimental). Data diolah dengan menggunakan statistik uji rata-rata (mean) dan uji Spearman correlation dengan tingkat kemaknaan $\alpha 0.05$. Berdasarkan hasil penelitian pada wanita dalam masa menstruasi menunjukkan kadar hemoglobin kurang dari normal, sehingga masa menstruasi berpengaruh terhadap kadar hemoglobin dan Masa Menstruasi berpengaruh terhadap Morfologi Eritrosit. Uji Statistik menggunakan Uji Correlation Spearman menunjukkan bahwa Rs hitung > Rs tabel maka $\mathrm{H}_{\mathrm{a}}$ diterima dan $\mathrm{H}_{\mathrm{o}}$ di tolak.
\end{abstract}

Kata Kunci : Masa Menstruasi, Kadar Hemoglobin, Morfologi Eritrosit

\section{PENDAHULUAN}

Menstruasi merupakan proses fisiologi pelepasan endometrium yang banyak terdapat pembuluh darah dan terjadi setiap satu bulan sekali. siklus menstruasi normalnya 25 sampai 32 hari. Sekitar $97 \%$ wanita yang mengalami ovulasi siklus menstruasinya berkisar antara 18 sampai 42 hari. masa remaja biasanya siklus menstruasi belum teratur. Jika siklus menstruasi kurang dari 18 hari atau lebih dari 42 hari dan tidak teratur, biasanya siklus menstruasi tidak berovulasi. Jumlah darah yang keluar di pengaruhi oleh umur dan gizi. Semakin tua umur wanita semakin banyak darah yang keluar (Prawirohardjo, 2005)

Pengeluaran darah selama menstruasi menunjukkan kehilangan simpanan zat besi secara cepat sesuai dengan banyaknya darah yang keluar sedangkan semakin lama wanita mengalami menstruasi maka semakin banyak pula darah yang keluar dan semakin banyak kehilangan timbunan zat besi. Oleh karena itu menstruasi merupakan golongan yang cenderung mengalami defisiensi besi. Wanita yang kehilangan darah sebesar $60 \mathrm{ml}$ atau lebih akan mengalami penurunan 
dalam hal ini jumlah simpanan zat besi. 10 dari 137 wanita akan menderita anemia defisiensi besi (kadar hemoglobin kurang dari $12 \mathrm{~g} / \mathrm{dl}$ ) dan hilangnya darah selama menstruasi rata-rata kelompok wanita anemis ini adalah $58 \mathrm{ml}$, di mana angka ini jauh lebih tinggi di bandingkan dengan angka rata-rata dari keseluruhan keompok (Fairus M, 2009)

Lama menstruasi dapat diukur berdasarkan hari pertama sampai hari terakhir keluar darah. Kehilangan zat besi di atas rata-rata dapat terjadi pada remaja putri dengan pola menstruasi yang lebih banyak dan waktunya lebih panjang (Proverawati, 2011).

Data dari World Healt Organization (WHO) tahun 2005 dalam setiasih (2007) menyebutkan bahwa $38,45 \%$ wanita di dunia mengalami permasalahan mengenai gangguan menstruasi. Menurut hasil penelitian yang dilakukan oleh American Collage of Obstetricians and Gynecologis dalam Saryono (2009) bahwa sedikitnya $85 \%$ dari wanita menstruasi mengalami minimal satu dari gejala Premenstruasi Syndrom dan umumnya terjadi pada wanita usia 14-50 tahun dengan gejala yang bervariasi dan berubah-ubah pada tiap wanita dari bulan ke bulan.

Penelitian yang dilakukan di Indonesia terkait dengan menstruasi menyatakan hasil yang tidak terlalu berbeda. Suatu penelitian yang disponsori oleh WHO tahun 2002 melaporkan $23 \%$ wanita indonesia mengalami syndrom premenstruasi. Penelitian lain terhadap 68 wanita usia produktif di Aceh besar melaporkan $41,18 \%$ respondennya menderita syndrom premenstruasi dalam kategori sedang (Nurmiaty, 2010).
Data dinas kesehatan Republik Indonesia tahun 1992, anemia diindonesia masih menjadi masalah kesehatan masyarakat yang mempengaruhi produktifitas penderitanya. Tercatat angka kematian ibu di negeri ini mencapai 390/100 ribu kelahiran hidup. Adapun data dari badan kesehatan dunia (WHO), 20\% dari 515.000 kematian di seluruh dunia yang di sebabkan anemia. Untuk menangkalnya, para wanita harus lebih banyak mengkonsumsi makanan yang banyak mengandung zat besi (BKKBN, 2009)

Jumlah darah yang keluar selama periode menstruasi normal telah dipelajari oleh beberapa kelompok peneliti yang menemukan bahwa jumlah berkisar antara $25 \mathrm{ml}$ sampai $60 \mathrm{ml}$. Pada konsentrasi hemoglobin $(\mathrm{Hb})$ normal yaitu 14 gr/dl dan konsentrasi besi $\mathrm{Hb} 3,4$ $\mathrm{mg} / \mathrm{gr}$, volume darah ini mengandung besi sekitar 12 sampai $19 \mathrm{mg}$ dan mencerminkan pengeluaran darah ekuivalen dengan 0,4 sampai $1,0 \mathrm{mg}$ besi setiap hari selama siklus, atau dari 150 sampai $400 \mathrm{mg}$ pertahun. Karena jumlah besi yang diserap dari makanan biasanya cukup terbatas, maka pengeluaran besi yang tampaknya tidak berarti ini menjadi penting karena ikut menurunkan cadangan besi yang pada sebagian besar wanita sudah rendah (Djariyanto, 2008).

Haid bulanan, menjadi salah satu penyebab anemia pada wanita. Walaupun demikian sangat disayangkan, banyak wanita menganggap bahwa penyakit ini dalam tahap ringan.

Wanita pada saat menstruasi mengalami lama siklus menstruasi yang berbeda-beda tergantung dari 
masing-masing orang namun semakin lama menstruasi, maka akan semakin rendah kadar hemoglobin, karena mengalami banyak pengeluaran darah sehingga wanita menstruasi lebih mudah mengalami anemia karena kadar hemoglobin dalam darah dibawah normal akibat karena kehilangan banyak darah.

Berdasarkan latar belakang diatas peneliti telah melakukan penelitian tentang pengaruh masa menstruasi berpengaruh terhadap kadar Hemoglobin dan Morfologi eritrosit

\section{METODE}

Jenis penelitian ini adalah penelitian eksperimen semu (quasi experimental), yakni melakukan uji laboratorium untuk menganalisa pengaruh masa menstruasi terhadap kadar Hemoglobin dan Morfologi eritrosit.

Populasi dalam penelitian ini adalah wanita yang mengalami menstruasi. Dalam pengambilan sampel, digunakan kuota sampling yaitu sampel sebanyak 20 subjek. Terdapat kriteria inklusi dalam pengambilan sampel yaitu masa menstruasi selama 6 hari. Teknik sampling pada penelitian ini menggunakan teknik kuota Sampling, yaitu cara pengambilan sampel dengan menentukan ciri-ciri tertentu sampai jumlah kuota yang telah ditentukan (Sugiyono, 2001).

Didalam penelitian ini kadar hemoglobin di ukur dengan menggunakan alat sysmex kx-21 metode Impedance. Sedangkan untuk pemeriksaan Morfologi Eritrosit dilakukan pemeriksaan secara langsung dengan pembuatan preparat Apusan Darah Tepi menggunakan pewarnaan Giemsa 1:7 selama 15 menit. Pembuatan Apusan Darah Tepi dibuat berdasarkan syarat yang berlaku yaitu : Tidak melebar sampai tepi kaca objek, panjangnya setengah sampai dua pertiga panjang kaca, Mempunyai bagian yang cukup tipis untuk diperiksa, pada bagian itu eritrosit terletak berdekatan tanpa bertumpukan, Rata, tidak berlubanglubang dan tidak bergaris-garis, Mempunyai penyebaran morfologi sel darah yang baik dan tidak berhimpun pada pinggir-pinggir atau ujung sediaan (Arif, M. 2009) Nilai rujukan untuk Laki -laki: 14,0 - 18,0 g/d. sedangkan nilai rujukan untuk Perempuan : $12,0-16,0 \mathrm{~g} / \mathrm{dL}$. Nilai rujukan untuk eritrosit dikatakan normal bila di dalam sediaan apusan darah, morfologi eritrosit tidak mengalami perubahan bentuk, warna dan ukuran.

Analisis Data

Analisa data digunakan analisa univariat dengan menentukan persentase hasil pemeriksaan haemoglobin dan analisa bivariate menggunakan Uji Rata-rata (mean) dan Spearman Correlation dengan menggunakan program SPSS.

\section{HASIL}

Penelitian ini dilakukan pada bulan Mei-April 2017, yang bertujuan untuk mengetahui pengaruh masa menstruasi terhadap kadar hemoglobin dan morfologi eritrosit. Dalam penelitian ini digunakan specimen darah vena pada wanita yang sedang berada dalam masa menstruasi, sebanyak 20 sampel. Hasil pemeriksaan dapat dilihat sebagai berikut: 
Tabel 1. Hasil pemeriksaan kadar hemoglobin pada wanita yang berada dalam masa menstruasi

\begin{tabular}{ccc}
\hline $\begin{array}{c}\text { Kode } \\
\text { sampel }\end{array}$ & $\begin{array}{c}\text { Masa } \\
\text { menstruasi } \\
\text { (hari) }\end{array}$ & $\begin{array}{c}\text { Kadar Hemoglobin } \\
(\mathbf{g} / \mathrm{dl})\end{array}$ \\
\hline 1 & 6 & $7,9 \mathrm{~g} / \mathrm{dl}$ \\
2 & 6 & $9,0 \mathrm{~g} / \mathrm{dl}$ \\
3 & 6 & $9,3 \mathrm{~g} / \mathrm{dl}$ \\
4 & 6 & $9,9 \mathrm{~g} / \mathrm{dl}$ \\
5 & 6 & $10,3 \mathrm{~g} / \mathrm{dl}$ \\
6 & 6 & $10,3 \mathrm{~g} / \mathrm{dl}$ \\
7 & 6 & $10,7 \mathrm{~g} / \mathrm{dl}$ \\
8 & 6 & $10,8 \mathrm{~g} / \mathrm{dl}$ \\
9 & 6 & $11,4 \mathrm{~g} / \mathrm{dl}$ \\
10 & 6 & $11,3 \mathrm{~g} / \mathrm{dl}$ \\
11 & 6 & $11,5 \mathrm{~g} / \mathrm{dl}$ \\
12 & 6 & $11,5 \mathrm{~g} / \mathrm{dl}$ \\
13 & 6 & $12,0 \mathrm{~g} / \mathrm{dl}$ \\
14 & 6 & $12,0 \mathrm{~g} / \mathrm{dl}$ \\
15 & 6 & $12,2 \mathrm{~g} / \mathrm{dl}$ \\
16 & 6 & $12,3 \mathrm{~g} / \mathrm{dl}$ \\
17 & 6 & $12,4 \mathrm{~g} / \mathrm{dl}$ \\
18 & 6 & $12,8 \mathrm{~g} / \mathrm{dl}$ \\
19 & 6 & $13,3 \mathrm{~g} / \mathrm{dl}$ \\
20 & 6 & $13,3 \mathrm{~g} / \mathrm{dl}$ \\
\hline
\end{tabular}

Sumber : data primer 2017

Tabel 2. Distribusi Frekuensi pemeriksaan kadar Hemoglobin pada wanita dalam masa menstruasi

\begin{tabular}{ccccc}
\hline No & Kategori kadar & $\begin{array}{c}(\mathbf{F}) \\
\text { frekuensi }\end{array}$ & $\begin{array}{c}(\%) \\
\text { persentase }\end{array}$ & Ket \\
\hline 1 & $<12,0 \mathrm{~g} / \mathrm{dl}$ & 12 & $60 \%$ & Anemia \\
2 & $12,0 \mathrm{~g} / \mathrm{dl}-14,0 \mathrm{~g} / \mathrm{dl}$ & 8 & $40 \%$ & Normal \\
3 & $>14,0 \mathrm{~g} / \mathrm{dl}$ & 0 & $0 \%$ & \\
& Total & 20 & $100 \%$ & \\
\hline
\end{tabular}

Sumber : Data Primer 2017

Uji rata-rata (mean) pada hasil pemeriksaan haemoglobin didapatkan hasil 11,21 g/dl yang menunjukkan kadar hemoglobin pada wanita dalam masa menstruasi kurang dari normal. 
Tabel 3. Hasil pemeriksaan Morfologi eritrosit pada wanita dalam masa menstruasi

\begin{tabular}{|c|c|c|c|}
\hline \multirow{2}{*}{$\begin{array}{l}\text { Kode } \\
\text { sampel }\end{array}$} & \multicolumn{3}{|c|}{ Hasil pemeriksaan Morfologi Eritrosit } \\
\hline & Ukuran & Bentuk & Warna \\
\hline 1 & Anisositosis & $\begin{array}{l}\text { Ovalosit, Target cell, Teardrop, } \\
\text { Akantosit }\end{array}$ & Hipokrom \\
\hline 2 & Anisositosis & Teardrop, Eliptosit, ovalosit & Hipokrom \\
\hline 3 & Normositik & Helmet, Ovalosit, Teardrop & Hipokrom \\
\hline 4 & Anisositosis & Sferosit, ovalosit & Normokrom \\
\hline 5 & Normositik & Akantosit, Teardrop, Helmet & Hipokrom \\
\hline 6 & Anisositosis & $\begin{array}{l}\text { Burr cell, Eliptosit, Akantosit, } \\
\text { Teardrop }\end{array}$ & Normokrom \\
\hline 7 & Normositik & Crenated cell, Target cell & Hipokrom \\
\hline 8 & Anisositosis & $\begin{array}{l}\text { Sel sabit, sferosit, ovalosit, } \\
\text { Eliptosit }\end{array}$ & Normokrom \\
\hline 9 & Anisositosis & $\begin{array}{l}\text { Teardrop, helmet, ovalosit, } \\
\text { sferosit }\end{array}$ & Normokrom \\
\hline 10 & Anisositosis & Eliptosit, Akantosit, Burr cell & Hipokrom \\
\hline 11 & Normositik & Teardrop, ovalosit & Hipokrom \\
\hline 12 & Anisositosis & Stomatosit, Crenated cell, Sferosit & Hipokrom \\
\hline 13 & Anisositosis & Target cell, Teardrop & Hipokrom \\
\hline 14 & Anisositosis & Crenated cell, Teardrop, Helmet & Normokrom \\
\hline 15 & Anisositosis & $\begin{array}{l}\text { Sferosit, crenated cell, eliptosit, } \\
\text { Teardrop }\end{array}$ & Normokrom \\
\hline 16 & Normositik & Target cell, ovalosit & Normokrom \\
\hline 17 & Normositik & Target cell, ovalosit & Normokrom \\
\hline 18 & Anisositosis & Crenated cell, ovalosit & Normokrom \\
\hline 19 & Normositik & Eliptosit, Ovalosit, Sferosit & Normokrom \\
\hline 20 & Normositik & Teardrop, Sferosit & Normokrom \\
\hline
\end{tabular}

Sumber : data primer 2017

\section{PEMBAHASAN}

Haid (menstruasi) adalah luruhnya lapisan dalam dinding rahim (lapisan mukosa uterus) yang banyak mengandung pembuluh darah yang terjadi secara berkala dan dikeluarkan melalui vagina, atau pendarahan periodik melalui vagina yang terjadi dengan pelepasan mukosa uterus (endometrium). Lapisan ini dibentuk sebagai persiapan jika sel telur (ovum) 
berhasil dibuahi oleh sel sperma (spermatozoid). Jika sel telur tidak dibuahi, maka lapisan jaringan ini akan meluruh.

Lama menstruasi dapat diukur berdasarkan hari pertama sampai hari terakhir keluar darah. Kehilangan zat besi di atas rata-rata dapat terjadi pada remaja putri dengan pola menstruasi yang lebih banyak dan waktunya lebih panjang (Proverawati, 2011).

Anemia terjadi ketika tubuh memproduksi terlalu sedikit sel darah merah, kehilangan terlalu banyak sel darah merah atau mematikan sel darah merah lebih banyak dari pada menggantinya. Penyebab umum dari anemia antara lain kekurangan zat besi, perdarahan usus, pendarahan, genetik, kekurangan vitamin B12, kekurangan asam folat dan ganggguan sumsum tulang (Islamiatun, 2015).

Lama hari perdarahan menstruasi dalam penelitian ini berkisar antara 6 hari. Berdasarkan Tabel 1 didapatkan hasil bahwa 12 subjek penelitian mengalami penurunan kadar Hemoglobin sedangkan 8 subjek penelitian dengan kadar Hemoglobin Normal.

Kurangnya hemoglobin dapat menyebabkan metabolisme tubuh dan sel-sel saraf tidak bekerja secara optimal, menyebabkan pula penurunan percepatan inpuls saraf, mengacaukan reseptor dopamine. Hasil pemeriksaan kadar hemoglobin pada wanita yang mengalami masa menstruasi menunjukkan 12 subjek (60\%) memiliki kadar hemoglobin kurang dari 12,0 g/dl dan termasuk dalam kategori anemia, dari beberapa subjek penelitian yang mengalami anemia berat dengan berbagai faktor penyebab terjadinya anemia, seperti kurang tidur disebabkan karena status pekerjaan, kurang mengkonsumsi gizi zat besi ketika sedang dalam masa menstruasi, adanya kelainan hormon, wanita yang sedang mengalami depresi dan banyak faktor lain yang dapat menyebabkan wanita dalam masa menstruasi mengalami penurunan kadar Hemoglobin.

Penurunan kadar hemoglobin disebabkan karena status gizi menurun, jumlah zat besi yang dikonsumsi tidak sesuai dengan jumlah yang dibutuhkan, misalnya karena asupan makanan yang mengandung zat besi kurang dan tidak mengkonsumsi tablet penambah darah saat sedang menstruasi. Selain itu berbagai faktor juga dapat mempengaruhi terjadinya penurunan kadar hemoglobin seperti umur, pola makan dan faktor genetik (Widjanarka, 2007).

Penurunan kadar hemoglobin yang disebut juga sebagai anemia mempengaruhi viskositas darah. Pada anemia berat viskositas darah dapat mengalami penurunan hingga 1,5 kali viskositas air. Keadaan ini mengurangi tahanan terhadap aliran dalam pembuluh darah perifer sehingga menyebabkan peningkatan curah jantung akibat jumlah darah yang mengalir melalui jaringan dan kemudian kembali ke jantung melebihi normal. Hipoksia yang terjadi juga membuat pembuluh darah perifer akan berdilatasi yang berakibat meningkatnya jumlah darah yang kembali ke jantung serta meningkatkan curah jantung dan peningkatan beban kerja pemompaan jantung (Gibson, J. 2005). 
Dari 20 subjek penelitian terdapat 8 subjek (40\%) dengan kadar hemoglobin normal. Hemoglobin normal ketika tubuh menerima asupan gizi dari sumbersumber makanan yang kaya akan Hemoglobin diantaranya yaitu seafood, daging, telur, produk susu, kacang-kacangan, sayuran, buah, rempah-rempah, biji-bijian dan coklat.

Hasil pemeriksaan Apusan darah tepi (tabel 3) berdasarkan warna eritrosit dapat dilihat pada tabel 3 terdapat 11 subjek penelitian yang menunjukkan warna eritrosit abnormal yaitu eritrosit hipokrom (eritrosit berwarna pucat) dan 9 subjek penelitian ditemukan dalam keadaan normokrom (warna eritrosit normal). 12 subjek penelitian ditemukan dengan bermacam macam ukuran eritrosit atau bentuk eritrosit abnormal (Anisositosis) dan 8 subjek penelitian ditemukan dengan ukuran eritrosit Normal (Normositik). Hal ini berarti pada wanita yang mengalami masa menstruasi kurang memproduksi $\mathrm{Fe}$ (zat besi) pada hemoglobin sehingga warna eritrosit menjadi pucat sesuai dengan pemeriksaan kadar hemoglobin yang banyak mengalami penurunan kadar hemoglobin. Kurangnya produksi $\mathrm{Fe}$ (Zat besi) disebabkan oleh wanita yang mengalami masa menstruasi terlalu banyak mengeluarkan darah sehingga terjadi anemia.

Warna eritrosit normal pada pemeriksaan morfologi eritrosit dari Apusan Darah Tepi adalah merah lembayung dengan daerah pucat pada bagian tengah, yang disebut akromia sentral yang luasnya antara $1 / 3-1 / 2$ kali diameter eritrosi. Bila daerah akromia lebih besar dari $1 / 2$ diameter disebut hipokrom, bila normal disebut normokrom (Rukman. K, 2014).

Dari 20 subjek penelitian yang memiliki bentuk eritrosit abnormal yang diantaranya yaitu ditemukan bentuk ovalosit, Target cell, eliptosit, sferosit, teardrop, akantosit, Helmet, Burr cell, sel sabit, Stomatosit dan Crenated cell. . Pemeriksaan morfologi eritrosit pada wanita yang mengalami masa menstruasi menggunakan mikroskop dengan pembesaran lensa objektif 100x dengan bantuan oil imersi.

Ukuran eritrosit normal (normositik) pada pemeriksaan morfologi eritrosit pada Apusan Darah Tepi adalah $6-8 \mu$ atau kurang lebih sama dengan besarnya inti limfosit kecil (Rukman. K, 2014)

Berdasarkan hasil pemeriksaan Morfologi Eritrosit didapatkan hasil 12 subjek anisositosis (bermacammacam ukuran eritrosit) dan 8 subjek Normositik yang berarti ukuran eritrosoit normal. Jadi sebagian besar ukuran eritrosit pada wanita yang mengalami masa menstruasi adalah anisositosis yang artinya dalam satu preparat didapatkan ukuran normositik-makrositik-mikrositik.

Hal ini disebabkan karena sedikit Fe (Zat besi) yang terikat, sehingga sintesis eritrosit terus berlangsung dan akhirnya menghasilkan eritrosit yang mikrositik, sedangkan eritrosit dengan ukuran makrositik berupa sel retikulosit dengan ukuran makrositik berupa sel retikulosit, yang menandakan terjadinya efektifitas eritropoesis oleh sumsum tulang. Bentuk eritrosit normal pada Apusan Darah Tepi adalah cakram bikonkaf dimana bagian tepi lebih merah 
daripada bagian sentralnya. Pelaporan dinyataka sebagai poikilositosis apabila dijumpai berbagai bentuk eritrosit (Rukman. $\mathrm{K}$, 2014).

Berdasarkan hasil analisa Data Uji statistik correlation Spearman pada wanita dalam masa menstruasi sebanyak 20 subjek penelitian menunjukkan bahwa Rs hitung > Rs tabel hal ini berarti $\mathrm{H}_{\mathrm{a}}$ diterima dan $\mathrm{H}_{\mathrm{o}}$ ditolak. Dengan demikian dapat disimpulkan bahwa masa menstruasi berpengaruh terhadap Morfologi eritrosit.

Uji correlation Spearman berdasarkan ukuran ertrosit pada wanita dalam masa menstruasi menunjukkan Rs hitung $1>\mathrm{Rs}$ tabel 0,377 hal ini berarti $\mathrm{H}_{\mathrm{a}}$ diterima dan $\mathrm{H}_{\mathrm{o}}$ ditolak, berdasarkan bentuk eritrosit pada wanita dalam masa menstruasi menunjukkan Rs hitung $1,003>$ Rs tabel 0,377 hal ini berarti $\mathrm{H}_{\mathrm{a}}$ diterima dan $\mathrm{H}_{\mathrm{o}}$ ditolak, berdasarkan warna eritrosit pada wanita dalam masa menstruasi menunjukkan Rs hitung $1>\mathrm{Rs}$ tabel 0,377 hal ini berarti $\mathrm{H}_{\mathrm{a}}$ diterima dan $\mathrm{H}^{\mathrm{o}}$ ditolak.

Pada pemeriksaan apusan darah tepi didapatkan sel eritrosit bentuk teardrop lebih banyak dari pada bentuk sel lainnya. Abnormalitas morfologi ini diakibatkan adanya perubahan hematopoiesis, bebasnya sel lebih awal dari sumsum tulang dan hematopoiesis akstramedular (Maani, St 2012)

Menurut Widjanarka (2007), faktor-faktor yang mempengaruhi kadar Hemoglobin adalah kehilangan darah akibat menstruasi, kurangnya zat besi dalam makanan yang dikonsumsi, penyakit yang kronis, pola hidup seseorang yang berubah, ketidak seimbangan antara asupan gizi dan aktifitas yang dilakukan

Selain itu wanita yang mengalami kadar hemoglobin yang rendah akan terjadi penurunan kadar zat besi sehingga mempengaruh morfologi eritrositnya. Untuk melakukan fungsi utamanya mengangkut oksige, eritrosit harus memenuhi beberapa kriteria Harus mempertahankan struktur bikonkaf untuk memaksimalkan pertukaran gas dan Harus lentur agar dapat masuk dalam kapiler mikrosirkulasi yang halus serta harus memiliki lingkungan internal yang konstan agar hemoglobin tetap berada dalam bentuk tereduksi sehingga dapat mengangkut oksigen (Handayani W dan Haribowo AS, 2008)

\section{KESIMPULAN}

Berdasarkan hasil penelitian tentang pengaruh masa menstruasi terhadap kadar hemoglobin dan morfologi eritrosit maka didapatkan hasil :

1. Wanita dalam masa menstruasi pada umumnya memiliki kadar hemoglobin yang kurang dari nilai normal sehingga masa menstruasi berpengaruh terhadap kadar hemoglobin.

2. Masa Menstruasi berpengaruh terhadap Morfologi Eritrosit.

\section{SARAN}

1. Pada wanita yang mengalami masa menstruasi perlu untuk menjaga pola makan agar ketika mengalami masa menstruasi berkepanjangan asupan gizi terimbangi sehingga kadar hemoglobin tetap normal dan morfologi eritrosit tidak banyak mengalami kelainan. 
2. Dapat melakukan perbandingan kadar hemoglobin dan morfologi eritrosit sebelum dan setelah menstruasi dengan masa menstruasi tidak normal.

\section{DAFTAR PUSTAKA}

Arif.M, 2009. Penuntun Hematologi

Makassar:

Fakultas

kedokteran Unhas

Djariyanto, 2008. Hubungan antara lama menstruasi dan kadar Hemoglobin pada remaja putri SMA Negeri 2 Sukoharjo. Universitas Muhammadiyah Surakarta.

Fairus M, 2009. Faktor-fajtor yang berkontribusi terhadap terjadinya anemia defisiensi besi pada remaja putri di SMU Muhammadiyah Kota Tegal. Universitas Indonesia, Jakarta.

Gibson, J. 2005. Fisiologi dan Anatomi Modern untuk perawat. Jakarta : EGC.

Handayani W dan Haribowo AS, 2008. Buku Ajar Asuhan Keperawatan pada Klien dengan Gangguan Sistem Hematologi. Jakarta : Salemba Medika.

Islamiatun, Hidayah AK dan Aryanti, 2015, Bidikan Jitu

$$
\begin{array}{lr}
\text { Lulus } \quad \text { UAS } & 2015, \\
\text { Tangerang: } & \text { Gading } \\
\text { Serpong. } &
\end{array}
$$

Maani,St, 2012, Gambaran Morfologi Eritrosit Pada Penderita Anemia Defisiensi Besi. Poltekkes Makassar.

Nurmiaty, 2010. Hubungan Perilaku makan dengan kejadian Sindrom premenstruasi pada remaja. (http://jurnal.ugm.ac.id/bkm /article/view /3407/2955) diakses 4 juli 2017

Praworohardjo, 2005. Ilmu Kandungan, Edisi 2 . Cetakan 4. Yayasan Bina Pustaka : Jakarta.

Proverawati, 2011. Anemia dan Anemia Kehamilan. Nuha Medika : Yogyakarta.

Rukman. K, 2014. Hematologi dan Transfusi. Jakarta : Penerbit

Saryono dan Sejati.W, 2009. Sindrom Premenstruasi, Yogyakarta: Nuha Medika

Wijdjanarka, 2017. Peran pola Makan Terhadap Anemia Gizi pada Remaja Putri Pondok Pesantren. Surabaya: Faculty of Public Health Airlangga University 